\title{
Triggering transitions towards sustainable development of the Dutch agricultural sector: TransForum's approach
}

\author{
A. VeldKamp*, A.C. Van Altvorst, R. Eweg, E. Jacobsen, A. Van Kleef, H. Van Latesteijn, S. Mager, \\ H. MOMMAAS, P.J.A.M. SMEETS, L. SPAANS, J.C.M. VAN TRIJP
}

TransForum, Louis Pasteurlaan 6, 2719 EE Zoetermeer, PO Box 80, 2700 AB Zoetermeer, The Netherlands.

(Accepted 24 May 2008)

\begin{abstract}
TransForum is an innovation program which aims to make a substantial contribution to the transition towards more sustainable development of the Dutch agricultural sector. This article describes the scientific foundation and architecture of this program. TransForum operates on the basis of five working hypotheses which together constitute one integrated analytical framework. These hypotheses are: (1) sustainable development is a dynamic system property; (2) sustainable development needs system innovation; (3) system innovation is a non-linear learning process; (4) system innovation requires active participation of relevant key players from knowledge institutes, governmental bodies, civil society organisations and the business community; (5) the program requires transdisciplinary collaboration of all players. TransForum identifies three new innovation strategies: (1) vital clusters; (2) regional development; (3) international agro-food networks; as alternatives to the current arrangements. Innovative projects are organised in these innovation strategies. The aim of the scientific program is threefold: (1) it addresses research questions raised in the innovative projects; (2) it investigates the need for system-innovations and the way in which they can be realized; (3) it designs research projects to test the 5 main working hypotheses of the program. The scientific program is organised in four themes following a cyclic innovation process which is constantly monitored. The cycle starts with people's preferences and images, followed by studies on which inventions are required to achieve a successful innovation. Subsequently, it is investigated how to organize new innovations and transitions and finally, how citizen/consumers behaviour and preferences mobilizes sustainable development, closing the loop.
\end{abstract}

sustainable development / transition / system innovation / networks

\section{INTRODUCTION}

Dutch agriculture and rural areas have changed dramatically during the last century (Maris and de Veer, 1973). Productivity soared due to new technologies, mechanization, increased chemical use, specialization and government policies that favoured maximizing production (van Dijk and Mackel, 1991). These changes allowed fewer farmers with reduced labour demands to produce the majority of the agricultural products. This development gave the Netherlands a strong agro-food sector but also changed the face of Dutch and European landscapes (Verburg et al., 2006a; Pedroli et al., 2007). The post-war development of knowledge was also directed towards high-productivity agriculture. As a result a knowledge infrastructure developed which focussed on new technology development for production maximisation. The implementation is still rather linear and top-down (Leeuwis, 2000). Research results are communicated to farmers by means of an

\footnotetext{
* Corresponding author: Tom.Veldkamp@wur.nl
}

extension service telling the farmer how to improve their production. While this approach was successful, it is now leading to overspecialization, environmental pressures and encroachment on public spaces (Wiskerke and van der Ploeg, 2004). These developments caused the Dutch agro-food sector to run into its ecological and social barriers (Dunn, 2003). Moreover, the Dutch agro sector is currently at risk of losing its 'license to produce' (social problem), 'license to operate' (policy problem) and 'license to deliver' (market problem).

TransForum was established in November 2004 in order to encourage the development of innovation oriented knowledge that would contribute towards more sustainable development in agriculture. TransForum is an innovation program that aims to provide a more sustainable development perspective for the Dutch agro-sector and rural areas by searching for and experimenting with new value propositions. TransForum's analytical framework is based on a set of new working hypotheses leading to a rather unconventional scientific program. It is the aim of this paper to demonstrate the unique features of the TransForum scientific program. 


\subsection{Analytical framework of TransForum}

TransForum operates on the basis of five hypotheses, which together constitute an analytical framework for both developing a more sustainable development perspective for the Dutch agro sector and an adaptation of the current knowledge infrastructure. These hypotheses are:

- sustainable development is a dynamic system property,

- sustainable development needs system innovation,

- system innovation is a non-linear learning process,

- system innovation requires a multi stakeholder approach,

- the TransForum approach requires transdisciplinarity.

These hypotheses deal with the concept of sustainable development, the relationship between this development and the need for innovation, the relevance of learning to achieve these innovations, the necessity of the involvement of all relevant stakeholders and the consequence of dealing equally with the knowledge that all the stakeholders bring with them, including tacit knowledge, and subsequently operating in a transdisciplinary mode. All five hypotheses will be explained below.

\subsubsection{Sustainable development is a dynamic system property}

Sustainable development rests on the principle that we must meet the needs of the present without compromising the ability of future generations to meet their own needs. Definitions of 'sustainable' agriculture are generally concerned with the need for agricultural practices to be economically viable, to meet human needs for food, to be environmentally positive, and to be concerned with quality of life. Sustainable development is characterised as the effort of finding a better balance between the Triple P (People, Planet \& Prosperity) triangle of relevant values (Elkington, 1998).

Since this better balance can be achieved in a number of different ways, sustainable development is not automatically linked to any particular technological practice or vision. Rather, sustainable development in agriculture can be looked upon as adaptability and flexibility over time when it comes to responding to changing demands and perceptions. These changes are typically related to food and other commodities, but also to shifts in socio-economic demands. In the Dutch context these shifts are apparently even more important than changes in demand for agricultural produce. Finally, it is important to realise that agriculture and regional development (green space) are all part of the same complex adaptive system, making it essential to address sustainable development as a system dynamic property (Fiksel, 2006). This view of agriculture as a complex adaptive system is a rather recent development but now a widely accepted model in system analysis (Liu et al., 2007).

\subsubsection{Sustainable development needs system innovation}

The current highly specialised agricultural system has become unable to cope with large-scale changes and disturbances. Examples are the recent crises caused by foot and mouth disease (Thomson, 2002) and the continuous political and societal debate regarding its license to produce. To overcome this barrier, there is a need to not only do things better, but to do better things. This calls for so-called system innovations or even transitions that enable the agro sector to develop apt alternatives.

Innovation is implementing a new value-proposition by means of a new, unique value chain. System innovation is the same, but for a system with multi-actor involvement (Porter, 1990). While innovation typically adds value, innovation may also have a negative or destructive effect as new developments do away with or change old organisational forms and practices (Driel and Schot, 2005). Innovation therefore typically involves risk. If system innovations are successful they may even lead to so-called transitions (Rotmans, 2003), a radical and structural change of the system as a whole.

\subsubsection{System innovation is a non-linear learning process}

The motto of the 1933 World Expo in Chicago was 'science finds, industry applies, man conforms'. This is the classic linear model of innovation: the idea that if you put enough money into science that after a while it will automatically lead to successful products, services and solutions for social problems. This way of thinking is referred to as 'Mode-1'. TransForum feels that system innovation, which includes both technical and social innovations, is not such a linear process. Science should interact more with users in order to generate successful products. This implies an innovation process with a lot of feedback. All this implies that 'learning' as feedback is crucial in innovation processes (Gibbons et al., 1994). Learning about technical capabilities, their possible applications, how to realise these applications and what the consequence could be. You can learn by searching, by doing, by using and by interacting. The learning process that follows these lines is referred to as 'Mode-2' (Gibbons et al., 1994; Nowotny et al., 2003). TransForum thinks that this Mode- 2 approach is essential to develop the needed system innovations. Characteristically, Mode 2 research groups are less firmly institutionalised; people come together in temporary work teams and networks, which dissolve when a problem is solved or redefined. Members may then reassemble in different groups involving different people, often in different loci, around different problems. The experiences gathered in this process create a competence which becomes highly valued and which is transferred to new contexts. Though problems may be transient and groups shortlived, the organisation and communication pattern persist as a matrix from which further groups and networks, dedicated to different problems, will be formed" (Gibbons et al., 1994). TransForum meets these typical Mode 2 characteristics it is a temporary organisation with temporary projects with a steady increase in human capital and experience along the way.

\subsubsection{System innovation requires multi stakeholder approach}

Since sustainable development deals with finding a better balance between people, planet and prosperity, and since 


\section{The TransForum network}

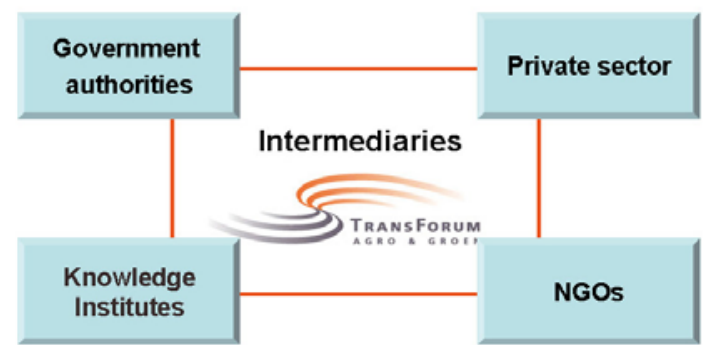

Figure 1. The TransForum network: knowledge institutes, governmental authorities, civil society organisations (including consumer organisations) and the private sector (including farmers). This network is referred to as KOMBI (= Dutch acronym) partners. TransForum is acting as an intermediary in the network.

learning should take place in a Mode- 2 fashion, the selection of participants in an innovation effort is essential. To ensure that all relevant values can play a part in attaining this better balance, representatives of differing views on sustainable development should be involved.

Within Dutch agriculture the current knowledge infrastructure (Agro-KIS) still plays an important role but with decreasing success. Knowledge is typically developed and disseminated by a top-down approach. It has now been recognized that this one-way top-down approach is insufficient to allow bottom-up interactions and feedback necessary for 'natural' diversification and system adaptation (Carpenter et al., 2001). This top-down approach also dominates current visions of sustainable development of the agro-sector. Consequently indicators of sustainable development have typically been defined by scientists and policy makers only. It is important to emphasise that reaching toward the goal of developing sustainable agriculture is the responsibility of all participants in the system, including farmers, labourers, policymakers, researchers, retailers, and consumers. Each group has its own part to play, its own unique contribution to make to strengthen the sustainable agriculture community.

TransForum therefore stimulates and organises collaboration between the four main players that together must take responsibility in the system innovation: knowledge institutes, governmental bodies, civil society organisations (including consumer organisations) and the business community (including farmers). This combination is referred to as KOMBI (= Dutch acronym) partners (Fig. 1). The process of involving all four partners is directed by TransForum by actively inviting and involving selected individuals from KOMBI organizations. This selection is based on individual experience of project directors who create and facilitate the necessary conditions for the projects, act as a link with the organisations involved and encourage the transfer and use of knowledge.

\subsubsection{TransForum approach requires transdisciplinarity}

Transdisciplinarity is seen as an integrative form of research, relating scientific knowledge and extra-scientific expe- rience and practice in problem-solving. In this understanding, transdisciplinary research addresses issues of the real world, not issues of origin and relevance only in scientific debate. A further important feature in understanding transdisciplinary research is whether and to what extent an integration of different scientific perspectives is addressed. This aspect is often used to distinguish between trans-, inter- and multi-disciplinarity (Pohl and Hirsch Hadorn, 2007).

We have used the four criteria, Lawrence and Després (2004) used to characterise transdisciplinarity research: (1) It tackles complexity in science and it challenges knowledge fragmentation. It goes beyond complexity and heterogeneity, this mode of knowledge production is also characterised by its hybrid nature, non-linearity and reflexivity, transcending any academic disciplinary structure; (2) It accepts local contexts and uncertainty; it is a context-specific negotiation of knowledge; (3) It implies intercommunicative action, which is a research process that includes the practical reasoning and knowledge of individuals (often refereed to as tacit knowledge (Polanyi, 1964)) with the constraining nature of social, organisational and material contexts; (4) It is often action-oriented, making linkages not only across disciplinary boundaries but also between theoretical development and professional practice (Giller et al., 2008). Transdisciplinary contributions frequently deal with real-world topics and generate knowledge that not only address societal problems but also contribute to their solution.

Given the complexity of the innovation problems encountered, the context specificity of the projects, the many stakeholders and their different roles and interests, and the action-oriented approach, and the different scientific disciplines involved the TransForum approach requires transdisciplinary research.

\section{TRANSFORUM'S PRACTICE PROGRAM}

\subsection{Three main innovation strategies}

TransForum's overall strategy is to let practice leading! In order to link firmly to current reality and practice, TransForum has organised $>20$ practice or innovative projects, in which the KOMBI partners attempt to overcome obstacles (real problems) concerning system innovation which prevent the current agro-sector from becoming a more sustainable system. There are three main clusters of practice projects aimed at different innovation strategies which intend to resolve pressing problems in the current system.

\subsubsection{Innovation strategy "Vital Clusters"}

The signalled over-specialisation and segregation of different agro-sectors and society forms an obstacle for innovation in the agro sector. In this innovation strategy projects are developed that create new value propositions by linking different systems in so-called vital clusters. Aside from the technical challenges, the concentration of many different functions at a 
Table I. The project portfolio of innovation strategy Vital Clusters comprising of 8 practice projects.

\begin{tabular}{|c|c|c|}
\hline New Mixed Farm & $2005-2008$ & $\begin{array}{l}\text { Agropark. Second, final phase almost concluded. Implementation of enterprise will start in } 2008 . \\
\text { Government regulation determines the speed of the innovation process. Entrepreneurs are now } \\
\text { setting up small scale business school on sustainable development. }\end{array}$ \\
\hline $\begin{array}{l}\text { Biopark Gent- } \\
\text { Terneuzen }\end{array}$ & 2006-2007 & $\begin{array}{l}\text { Agropark. Second, final phase almost concluded. Implementation of enterprise will start in } 2008 . \\
\text { Tuning of process flows and business models between different enterprises proofs very difficult. }\end{array}$ \\
\hline Greenport Shanghai & 2006-2007 & $\begin{array}{l}\text { Agropark. Start in 2006. Strongly building on network of New Mixed Company. Master plan } \\
\text { finished. Implementation starts with business planning. Getting the innovative combination of } \\
\text { Knowledge Institutes, Entrepreneurs, Governmental and Non-governmental organisations } \\
\text { working is the is pre-dominating problem }\end{array}$ \\
\hline SynErgie & 2005-2008 & $\begin{array}{l}\text { Learning network on Energy in Greenhouses. Second phase almost concluded. Created a learning } \\
\text { network now evolving into a Community of Practice. Strong emphasis on communication with } \\
\text { early adapters via seminars. Successful programming of scientific projects. }\end{array}$ \\
\hline $\begin{array}{l}\text { Unsolicited Proposal } \\
3^{\text {rd }} \text { Ring of } \\
\text { Amsterdam }\end{array}$ & 2007 & $\begin{array}{l}\text { Regional approach to accessibility of Greenport. Formulating "Problem as conceived by all } \\
\text { stakeholders" is major effort in first phase. Result of successful co-operation between TransForum } \\
\text { and Transumo. }\end{array}$ \\
\hline Drive & 2005-2007 & $\begin{array}{l}\text { Quality control in pig chain. Project has been closed after first phase. Efforts concentrated almost } \\
\text { fully on optimization of internal operational aspects of slaughterhouse company. }\end{array}$ \\
\hline $\begin{array}{l}\text { Healthy Pip Fruit } \\
\text { Chain }\end{array}$ & 2005-2007 & $\begin{array}{l}\text { Introduction of cis-genetic modification to speed up race development in fruits. Efforts concentrate } \\
\text { on technical innovation, which gives the project the character of a scientific project in stead of an } \\
\text { innovative practice project. }\end{array}$ \\
\hline Dairy Adventure & 2007-2010 & $\begin{array}{l}\text { Three regional specific experiments with dairy farming beyond the scale of family farms, which } \\
\text { are characteristic for the Netherlands. Application of knowledge and experiences from Dutch } \\
\text { emigrants that started large dairy farms all over the world. Set up of an international Community } \\
\text { of Practice. }\end{array}$ \\
\hline
\end{tabular}

single location is currently almost impossible in the Netherlands due to the (over)regulations related to environmental and zoning plans. Table I gives an overview of the practical projects of Vital Clusters.

\subsubsection{Innovation strategy "Regional Development"}

The traditional, dominant agricultural focus when dealing with rural areas is also blocking innovations. The majority of the Dutch people view rural areas as recreational and settlement areas. Subsequently their demands with regard to the landscape are different from the demands farmers have. As a result current regulations have started increasingly restricting farmers in the development of new agricultural activities. To facilitate these changing spatial claims by different users, a transition towards a economically viable, yet socially acceptable agriculture is required. Projects in the innovation strategy Regional Development are characterised by an integrated systems approach to rural regions. Table II gives an overview of the project portfolio.

\subsubsection{Innovation strategy "International Agro-food Networks"}

The traditional focus on primary production comes into conflict with the reality that nowadays many products are cheaper to import then to produce. In this innovation strategy projects are stimulated that focus on the transition of the Dutch agro-sector towards adopting a role of knowledge broker and organiser in the international agro sector. Therefore the strategy is referred to as international agro-food networks, since it has to deal with the position that Dutch businesses can attain in the international arena.

In the innovation strategy TransForum wants to develop alternative ways of creating added value in international agro food networks. Table III gives an overview of the project portfolio.

\subsubsection{Practice projects in each innovation strategy}

Project portfolios with innovative practice projects (Tabs. IIII) are linked to each innovation strategy. The aim is to have representatives of all KOMBI partners involved in these projects, facilitated by TransForum. The approach in all projects is based on learning by doing whereby practical, real world problems are the drivers. In these projects together with entrepreneurs and other stakeholders TransForum tries to discover new pathways to more sustainable development of agriculture and thriving rural areas.

The innovative practice projects not only produce practical knowledge that can be applied instantaneously, but also usable methods for generating that knowledge. This creates a new knowledge network that satisfies two requirements: (1) close 
Table II. The project portfolio of the innovation strategy 'Regional Development' comprises of six practice projects which can be regarded as regional niche experiments.

\begin{tabular}{l|l|l}
\hline Northern Frisian Woods & 2004-2006 & $\begin{array}{l}\text { Project concluded and results published in Working Paper 6. Supported the farmers' } \\
\text { organisation NFW in their aim for self regulation in environmental and landscape } \\
\text { management. A 'regional contract' was developed and space for experiments created. }\end{array}$ \\
\hline De Sjalon & $2006-2008$ & $\begin{array}{l}\text { Phase 1 is concluded. The development of a large scale arable enterprise in the NoodOost } \\
\text { Polder, by merging arable farms in collaboration with dairy farms and chain partners. } \\
\text { A business plan has been developed; the start of the new company is foreseen in 2008. }\end{array}$ \\
\hline $\begin{array}{l}\text { Green Valley process } \\
\text { evaluation }\end{array}$ & 2006 & $\begin{array}{l}\text { The project Green Valley never started. This evaluation investigates success and failure } \\
\text { factors and lessons learned. Results published in a report. }\end{array}$ \\
\hline Brackish Agriculture & $2006-2010$ & $\begin{array}{l}\text { Experiments and research of new Brackish Crops both in laboratory and field circumstances. } \\
\text { Focus on plant properties and cultivation techniques, product and market development. Field } \\
\text { experiments have been started in a brackish polder (the Island Texel). }\end{array}$ \\
\hline $\begin{array}{l}\text { Green Care Amsterdam } \\
\text { Streamlining Greenport }\end{array}$ & $2006-2009$ & $\begin{array}{l}\text { Developing of a cooperation of Care Farms and Educational Farms, in collaboration with } \\
\text { care organisations and schools. The cooperation, now consisting of 20 farmers, has been } \\
\text { recognized by the national health insurance. }\end{array}$ \\
\hline $\begin{array}{l}\text { Venlo } \\
\text { coalitions South Limburg } \\
\text { ('Heerlijkheid }\end{array}$ & $2005-2008$ & $\begin{array}{l}\text { A network of entrepreneurs and local governments is supported who are developing the } \\
\text { 'Greenport Venlo' a dynamic region in Northern Limburg, on 'food, feed and flowers'. Focus } \\
\text { on learning processes by organising and facilitating Communities of Practice. }\end{array}$ \\
\hline
\end{tabular}

partnership between research and practice; (2) cooperation between divergent disciplines in order to come up with integrated practical solutions. As a consequence the Practice Programme features strong interaction between science and practice.

The three innovation strategies fit well with the ideas presented in "The Information Age: Economy, Society and Culture" of Manuel Castells (e.g. 1996, 1997), proclaiming the arrival of a network society in which the dynamics of a space of flows were thought to supersede the space of places. Regional development represents new combinations of activities for rural areas, representing the 'space of places' following Castells (1997) (Fig. 2).

International agro-food networks represent new transfrontier production and trade networks in which the Dutch can have their own specific niche, representing the 'space of flows'. Vital clusters are new combinations of economic sector in spatially concentrated clusters, were the 'space of places' and the 'space of flows' meet each other. Regional development resembles the 'regions' discussed by Porter (2003), while the vital clusters are in line with the 'local clusters' of Porter (2000).

\subsection{The supporting role of science and knowledge}

Firstly, the Scientific Programme contributes by research activities that are aimed at delivering solutions and instruments to develop new value propositions. The relationship between the innovative practice projects and the scientific projects in these cases is fairly straightforward. In the practice projects the research questions are formulated and the results of the scientific project will contribute directly to the success of the developed value propositions. The approach in these research

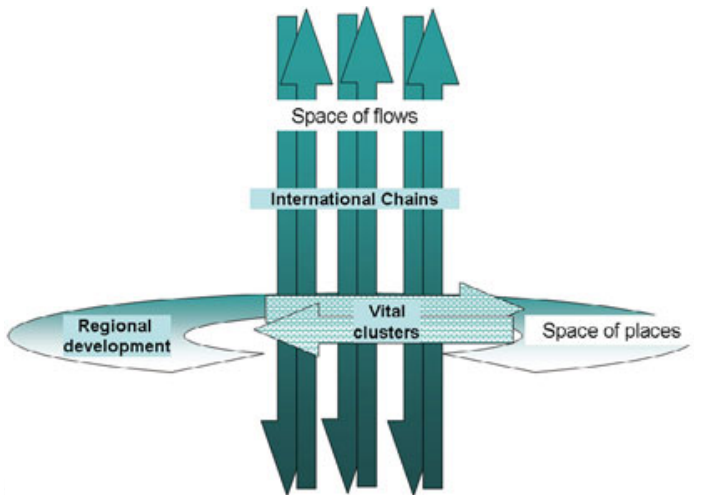

Figure 2. Illustration of how TransForum's three innovation strategies fit with the ideas presented in "The Information Age: Economy, Society and Culture" (Castells, 1996, 1997). Regional development represents new combinations of activities for rural areas, representing the 'space of places' of Castells (1997). International agro-food networks represent new trans-frontier production and trade networks in which the Dutch agro sector can have its own specific niche, representing the 'space of flows'. Vital clusters are new combinations of economic sector in spatially concentrated clusters, were the 'space of places' and the 'space of flows' meet each other.

activities is not so much transdisciplinary as well as interdisciplinary: in formulating the research question, in exchanging information with the practice project and in the application of the results a tight connection between scientific knowledge and the domain of practical experience is made.

Secondly, within the scientific programme the need for system-innovations and the way in which they can be realized is an object of research. For that reason the scientific programme uses the practice projects - amongst other things 
Table III. The project portfolio 'International Agrifood Networks' comprises of eight projects that together deliver new insights in how to develop alternative ways of creating added value in international agro food networks. The projects span a wide range of topics and also differ greatly in focus.

\begin{tabular}{|c|c|c|}
\hline Calendula & 2004-2007 & $\begin{array}{l}\text { An innovative, international agro industry chain for renewable raw materials is developed. } \\
\text { Concrete spin-off of the project is the start of a new company "Calendula Oil BV" that will bring } \\
\text { Calendula Oil on the market. FEM-Business Magazine recently selected Calendula Oil BV as one } \\
\text { of the } 25 \text { 'most promising' start ups. }\end{array}$ \\
\hline $\begin{array}{l}\text { Everything } \\
\text { About Food }\end{array}$ & 2005-2008 & $\begin{array}{l}\text { This project has resulted in the development of the website www.meerovereten.nl. Consumers } \\
\text { can find production information to easily compare sustainability performances of various food } \\
\text { products. The consumer information thus generated can be used by participating industries and } \\
\text { retailers for new, sustainable value propositions. }\end{array}$ \\
\hline $\begin{array}{l}\text { Sustainability in } \\
\text { Retail }\end{array}$ & 2006-2008 & $\begin{array}{l}\text { This project offers TransForum the possibility to find out whether a pull strategy through retail } \\
\text { can speed up the transition towards a more sustainable agro food production and how a transition } \\
\text { approach of strategic stakeholder partnership works out in practice. }\end{array}$ \\
\hline $\begin{array}{l}\text { Regional Food } \\
\text { Chains }\end{array}$ & 2007-2008 & $\begin{array}{l}\text { A new chain will be developed in which the traditional hypermarket chain is no longer the only } \\
\text { company that is communicating with consumers. The primary producers are also responsible for } \\
\text { merchandizing their products in the retail to the consumers. In this project the hierarchies in the } \\
\text { chain are changed. The consequences of this change will be analySed both for supermarket and } \\
\text { for producers. }\end{array}$ \\
\hline $\begin{array}{l}\text { Healthy with Oats } \\
\text { (phase 1) }\end{array}$ & 2007-2008 & $\begin{array}{l}\text { A new chain will be developed with high quality products on the basis of guaranteed gluten free } \\
\text { oats. (At this moment a chain with } 100 \% \text { gluten free does not exist). Gluten free oats will con- } \\
\text { tribute to the reduction of an important social healthy problem of a growing group of celiac patients } \\
\text { ( } 2 \% \text { of the population). }\end{array}$ \\
\hline $\begin{array}{l}\text { Laying Hen } \\
\text { Husbandry } \\
\text { (phase 1) }\end{array}$ & 2007-2008 & $\begin{array}{l}\text { The project aims to realize a system innovation in the table egg sector. The actual laying hen } \\
\text { production systems still have many veterinary, environmental and animal welfare problems. The } \\
\text { desired system innovation is triggered by building a totally new chain which is able to quickly } \\
\text { adapt to changing market demands. }\end{array}$ \\
\hline $\begin{array}{l}\text { International } \\
\text { Livestock } \\
\text { coordinating Role }\end{array}$ & 2005-2006 & $\begin{array}{l}\text { This project was focusing on transforming the entire livestock farming chain into sellers of knowl- } \\
\text { edge and services in international markets. The aim of the project to develop a strategy to exploit } \\
\text { this knowledge has not been obtained in this project. Therefore, TransForum requested a transition } \\
\text { analyses. From this analysis, it was concluded that the different companies did not have a shared } \\
\text { vision on a sustainable pig sector. }\end{array}$ \\
\hline $\begin{array}{l}\text { Flor-i-Log } \\
\text { orchestration }\end{array}$ & 2004-2008 & $\begin{array}{l}\text { Aim of the project was to investigate how international orchestration of the horticultural sector } \\
\text { could be achieved. In this project Dutch flower auctions and wholesalers are looking for new } \\
\text { organisational and logistic models to maintain the Dutch leading position in the international } \\
\text { floricultural sector. Goal is to seriously diminish unnecessary transport of floricultural products. } \\
\text { Scientist and chain members have analysed international market possibilities and developed a } \\
\text { logistic model for efficient transport. At the moment the challenge is to develop an international } \\
\text { business model from this. }\end{array}$ \\
\hline
\end{tabular}

- as the primary source of information. In almost all practice projects some experimenting is going on with needed systeminnovations. The scientific projects use this experimental information to reflect on the findings and combine the practical experiences with scientific insights on sustainable development, on inventions, innovations and transitions. So, learning from practice leads to obtaining insights in the needed knowledge, the required competences and the necessary transitions. Based on this learning approach the four themes for the scientific programme have been identified, which will be discussed later.

Thirdly, the scientific programme is also aimed at testing TransForum's analytical framework. And following up on that, the assumption is tested that working along this framework will indeed lead to new value propositions and will indeed lead to the desired influence on current knowledge infrastructure. To focus the attention on these issues a fifth overarching theme in the scientific programme has been set up. The main aim of this fifth theme is self reflection and learning within the scientific program.

In these three ways, the scientific programme intents to look upon the issue of sustainable development and innovations in multiple ways:

- by the different emphasis in strategy on doing and learning;

- by discerning between a number of different themes and research questions;

- by working in multi- and interdisciplinary modes;

- by striving towards an open-source approach by sharing knowledge and insights in a self reflection loop (Fig. 3). 


\subsection{Knowledge development}

Central in knowledge development is the way we learn. TransForum has organised the learning in a triple loop perspective. Single loop learning is done by directly serving of technical questions from the practice projects, given incremental improvement. The reflection in the double loop learning (Argyris, 1994) is organised in the scientific program, causing reframing concepts and change in opinions and values. The triple-loop learning is organised in specific learning programs. Triple loop learning involves transforming who we are by creating a shift in our context or point of view about ourselves (Argyris, 1999).

The learning programme is a combined learning and reflection programme. The focus is not on the classical building up and transferring knowledge, but rather on organising reflection and learning, developing the competencies and skills for innovation, and giving back and embedding these insights by means of learning arrangements and training programmes

\section{TRANSFORUM'S SCIENTIFIC PROGRAM}

The scientific programme was developed in 2005 and 2006. The aim was to develop a programme that was innovative in terms of scientific progress as well as societal usefulness. Knowledge issues arising from innovative practice projects form the basis for the agenda-setting of the scientific programme.

In several working sessions the scientific directors of TransForum have developed a thematic programme that enables the production of useful insights in the innovation process needed for a more sustainable development. A general observation in the practice projects was that the linear idea of innovation, where knowledge creation precedes valorisation, did not apply. In stead, the projects almost without exception demonstrated that knowledge creation and valorisation (or value creation) occur simultaneously in a cyclic non-linear innovation process. In this process, focussing on visions of sustainable development lead to inventions, inventions lead to innovations and innovations influence consumer behaviour. To close the loop this consumer behaviour influences the perception of issues related to sustainable development.

\subsection{Science process}

Making the transition to more sustainable development of agriculture is a process. For scientists and farmers alike, this transition will require a series of small, realistic steps. It is important to realize that each small decision can contribute to advancing the entire system further on the "sustainable agriculture development continuum". The key to moving forward is the will to take the next step. Also TransForum learns by doing. Initially, TransForum was trying to give direct answers, such as improved designs, drafting new structures and methods. After organizing and executing several practice innovation projects the emphasis has shifted towards investigating

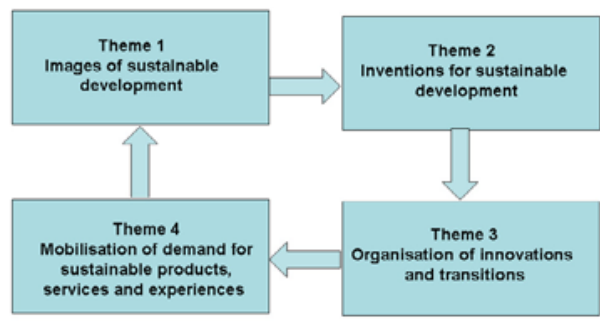

Learning loop and self reflection Scientific themes

Figure 3. TransForum's scientific program is organised in four themes following a cyclic innovation process which is constantly monitored. The cycle starts with 1: people's preferences and images, followed by 2 : studies on which inventions are required to achieve a successful innovation. Subsequently, 3: it is investigated how to organize new innovations and transitions and finally, 4: how citizen/consumers behaviour and preferences mobilizes sustainable development, closing the loop. The box represents the fifth theme on self reflection providing the means to evaluate the effectiveness and efficiency of the learning system.

the (boundary) conditions for more sustainable development. It is now the aim to promote the interaction between different types of knowledge, ensuring that this leads to joint innovations, and working to ensure people, organizations and systems get the knowledge and skills to work together and create innovations. In this way, TransForum intends to achieve more relevant, permanent results than it would achieve if it were to strive for technically substantive results which have been defined as sustainable on the basis of normative choices.

The quality of research is guaranteed through a classic scientific quality assessment system with external project and paper review. We are still developing a quality assessment system to evaluate the effectiveness of the research for the stakeholders in the practice projects.

\subsection{Science contents}

A main scientific content requirement is that TransForum has to determine what it means with sustainable development. Within many different projects and its participants there are different concepts of sustainable development. Discussion about how sustainable a product or process is, often leads to a never ending debate on the 'best' sustainable development indicators. This illustrates that the debate about sustainable development is normative and that the ultimate sustainable system doesn't exist. In order to stimulate more sustainable development of the agricultural sector TransForum investigates the generic dimensions of sustainable development that play a role in the expression of subjective preferences. This approach is phrased in hypothesis 1 .

TransForum identified as generic dimension of sustainable development the resilience or adaptive capacity of the agricultural sector. Adaptive capacity in ecological systems is related to genetic diversity, biological diversity, and the heterogeneity of landscape mosaics (Carpenter et al., 2001). In social 
systems, the existence of humans, institutions and networks that learn and store knowledge and experience, create adaptive capacity in problem solving (Berkes et al., 2003; Lebel et al., 2006). Systems with high adaptive capacity are able to re-configure themselves without significant declines in crucial functions in relation to primary productivity, hydrological cycles, social relations and economic prosperity. A consequence of a loss of resilience, and therefore of adaptive capacity, is loss of opportunity, constrained options during periods of reorganisation and renewal, an inability of the system to change. Transitions are needed in order to allow social-ecological systems to emerge from an undesirable trajectory. Resilience is seen as the key to enhancing adaptive capacity and facilitates system transitions. Resilience reflects the degree to which a complex adaptive system is capable of self-organization, versus lack of organization or organization forced by external factors, and the degree to which the system can build capacity for learning and adaptation (Carpenter et al., 2001). But selforganization is often constrained by institutional factors, particularly policies operating an National. supra national (EU) (e.g. CAP) and international levels (Cafiero, 2007). By focussing on the generic dimensions of resilience and/or adaptive capacity TransForum expects it will be possible to depict and create alternative acting perspectives and value propositions how to deal with preferences instead of becoming part of the discussion (Anderies et al., 2004).

Innovation is the key to how actors in a coupled socioecological system, like the Dutch agricultural sector, can adapt. It is therefore essential to combine the insights and knowledge of innovation studies in the resilience concept (Newman, 2005). Resilience and innovation are intrinsically linked. Only in a resilient system, change has the potential to create opportunity for development, novelty and innovation. Sustainable development is dynamic and needs to build on the notion of resilience. Innovation is essential to maintain resilience in changing environments where the future is unpredictable and surprises are likely.

Since adaptive learning is a central concept in the scientific program of TransForum the scientific themes are organised in a co-learning or co-production cycle (Martens, 2006) (Fig. 3). Each theme is oriented towards answering questions which aim to help the KOMBI partners to achieve more sustainable development in practice by means of a causal learning loop. The box in Figure 3 represents the fifth overarching theme on self reflection providing the means to evaluate the effectiveness and efficiency of the learning system.

Each theme has one or two main research questions:

- Theme 1: 'Images of sustainable development': How to deal with the preferences of the various actors in the field, rather than normative statements about what sustainable development is or should be?

- Theme 2: 'Inventions for sustainable development': What inventions are needed in order to make a breakthrough in the practical projects, and how to encourage the KOMBI partners to work towards this and deploy their knowledge to achieve it (= content and process aspects)?
- Theme 3: 'Organisation of innovations and transitions': What encourages or hinders the cooperation of KOMBI partners?

- Theme 4: 'Mobilisation of demand for sustainable products, services and experiences': How does the behaviour of citizens and consumers affect the likelihood of innovations being achieved? How can this behaviour be harnessed to promote sustainable development?

Knowledge issues arising from innovative practical projects are taken further in scientific projects. This is done with the aid of (multi)-disciplinary alliances. Only in this way new insights can be gained for solving practical problems. Every scientific project comes under one of the following themes:

\subsubsection{Theme 1: Images of sustainable development}

Goal: explore the subjective visions of sustainable development by introducing the concept of resilience (adaptive capacity).

In order to stimulate more sustainable development of the agricultural sector TransForum investigates the generic system dimension of resilience in the context of sustainable development. It is a main hypothesis that when an innovation leads to an increase in system resilience this will contribute to more sustainable development. In order to test this hypothesis theme 1 will translate the concept of resilience into:

- triple P (People, Planet, Prosperity) context;

- different 'currencies' of the main stakeholders (money, power, scientific standing and impact);

- different scientific paradigms.

Theme 1 will make an inventory of the current practical innovation projects answering the following questions:

- Which (un)sustainable development images are aimed for?

- Which dimensions are considered relevant/important for success?

- Which dimensions can be linked to resilience?

- Which dimensions are linked to the three innovation strategies of TransForum?

By making these steps the scientific theme 'Images of sustainable development' will develop an operational sustainable development concept that will give entrepreneurs and other stakeholders inspiring and guiding action perspectives. At the level of the whole system it is expected that this operational concept will contribute to a more resilient agro-system. The complex adaptive system properties of the system imply that this can only be done in inter- and trans-disciplinary research setting.

\subsubsection{Theme 2: Inventions for sustainable development}

Goal: Identify and stimulate inventions that will overcome the barriers towards sustainable development. 
In the practical innovative projects of TransForum different innovations are implemented based on various images of sustainable development. The demanded changes often require new inventions. These inventions can be hardware, software or org-ware (organisations and institutions) oriented. This requires a clear articulation of the inventions desired on the one hand and on the other hand how to stimulate the development of such new inventions. It is important to emphasize that all available knowledge should be used and considered from high tech academic knowledge to tacit knowledge of entrepreneurs.

All inventions aim at solving sustainable development demands raised by ongoing practical projects. Development and implementation of inventions doesn't follow the linear topdown process of research, application and valorisation. Current institutional arrangements such as patents and breeding rights tend to obstruct joined development of new inventions.

Theme 2 will address the following research questions:

- Which type of inventions can contribute to breakthroughs in the three innovation strategies?

- How can inventions be stimulated which require participation of all KOMBI partners?

- How can we get effective access to all knowledge and experience of all relevant stakeholders?

\subsubsection{Theme 3: Organisation of innovations and transitions}

Goal: Developing conceptual scenarios for organizing innovations and transitions in the three innovation strategies.

System innovation can only happen when the KOMBI partners collaborate. In the real world this collaboration is not that self-evident. Why is this not the case? Which images, values, laws, rules, power distribution etc. hampers this collaboration towards more sustainable development of the Dutch Agro-sector? Are these obstructions the same for all three innovation strategies? And when we know the obstruction are we able to define concrete action perspectives in order to resolve these innovation blockades?

Central in theme 3 is the 'regime' concept. A regime is a system of systems, an interplay of structure, culture and approaches which lead towards a set of rules and resources which maintain the current status quo. Regimes can be influenced by developments in niches, which eventually lead to transitions of the regime (Stoker and Mossberger, 1994). The main research questions of theme 3 are:

- What are the characteristics of the current regime which leads to self-enforcing of the current agricultural system?

- How does the current regime stimulate or obstruct the desired innovations toward more sustainable development within the three innovation strategies?

- What design criteria for a more innovative regime can we deduct from the current experience in the practical innovative projects?

- Which concrete action perspectives of the KOMBI partners lead to these design criteria?

\subsubsection{Theme 4: Mobilisation of demand for sustainable products, services and experiences}

Goal: Understanding the triggers and barriers for the expression of individual social responsibility in actual purchasing and consumption behaviour with respect to sustainable development

Sustainable development is also stimulated by the demands of consumers and civilians. Civilians have a direct cumulative effect by setting political agendas that demand for example public goods such as a clean environment and a healthy working environment. But as consumers people make choices for certain products and services as offered by the market. Both types of demand are often not in agreement and have a strong impact on the achievability of sustainable development.

Within the three innovation strategies of TransForum different experimental projects are set up to study civilian and consumer demands. The final goal is to combine these two demands and address the issue of Individual Social Responsibility. Theme 4 investigates how the consumers can be more involved in the development of the individual social responsibility as a method to enhance sustainable development of the agro-sector. The main research questions are:

- How do stakeholders mobilize the consumer demand for sustainable development?

- How do stakeholders mobilize the civilian demand for sustainable development?

- Which unifying concepts can be developed to visualize consumer/civilian demands for sustainable development?

- Does the combination of the consumer and civilian approaches lead to a useful concept of 'Individual Social Responsibility' which can contribute to more sustainable development?

\section{CONCLUSION}

TransForum aims to be a learning organisation. In order to learn (double loop learning) from our scientific themes and projects a Community of Scientific Practice (CSP) is organised (Bouma, 2005). A CSP consists of a close, interacting team in which some do fundamental, applied or strategic research, while others participate in Communities of Practice (COP) at TransForum the practice projects, and still others focus on design, policy issues, management and communication. Interaction among team members leads to joint learning and, as a consequence, a more effective team effort. Team members will contribute their specific skills to education as needed.

The overall lines of the innovation program TransForum have been sketched. The ultimate goal is to stimulate transitions towards sustainable development of the Dutch agricultural knowledge infrastructure. TransForum is a learning reflective organisation, which means that we are willing reformulate our goals when there are sufficient indications to do so. Preliminary results from our practical projects indicate that most obstructions for innovations have an institutional character. Many current structures and regulations are hampering 
effective and quick changes in the current agro-sector, a finding not uncommon in Europe (Cafiero et al., 2007).

One important dimension currently not discussed in the research plan is the European and international dimension. More and more regulations and subsidies from the EU influence and affect the agro-sector and rural development. Preliminary studies have indicated (Verburg et al., 2006b) that these policies have potentially large impacts in the landscape development of the EU member states. It is the goal of TransForum to elaborate more on this international dimension. Internationally TransForum tries to seed similar initiatives in other settings and conditions. That is why TransForum has made a Memorandum of Understanding with KOMBI partners in Michigan (US) and KOMBI partners in Shanghai (China) to stimulate similar transitions in global key countries for the agro-food sector.

Acknowledgements: This article has benefited form the useful and constructive remarks made by two anonymous reviewers and a field editor.

\section{REFERENCES}

Argyris C. (1994) Initiating Change That Perseveres, J. Public Administration Res. Theory: J-PART 4, 343-355

Argyris C. (1999) Organizational learning: A theory of action perspective, Blackwell publ. Addison Wesley, $560 \mathrm{p}$.

Anderies J.M., Janssen M.A., Ostrom E. (2004) A framework to analyze the robustness of social-ecological systems from an institutional perspective, Ecol. Soc. 9, 18.

Berkes F., Colding J., Folke C. (Eds.) (2003) Navigating SocialEcological Systems: Building Resilience for Complexity and Change, Cambridge University Press, Cambridge, UK.

Bouma J. ( 2005) Agenda for Future Research, in: Koeman J.H., Schiereck J.D. (Eds.), Responsibilities of Environmental Research, KNAW, Amsterdam.

Cafiero C., Capitanio F., Cioffi A., Coppola A. (2007) Risk and Crisis Management in the Reformed European Agricultural Policy, Can. J. Agr. Econ. 55, 419-441.

Carpenter S., Walker B., Anderies J.M., Abel N. (2001) From metaphor to measurement: Resilience of what to what? Ecosystems 4, 765-781.

Castells M. (1996) The Information Age: Economy, Society and Culture, Blackwell Publishers, Malden (Mass) and Oxford, Vol. I: The Rise of the Network Society, $556 \mathrm{p}$.

Castells M. (1997) The Information Age: Economy, Society and Culture, Blackwell Publishers, Malden (Mass) and Oxford, Vol. II: The Power of Identity, 461 p., Vol. III: End of Millennium, 418 p.

Dijk G., van, Mackel C. (1991) Dutch agriculture seeking for market leader strategies, Eur. Rev. Agr. Econ. 18, 345-364.

Driel H. van, Schot J.(2005) Radical innovation as a multi-level process, Technol. Cult. 46, 51-76.

Dunn E.C. (2003) Trojan pig: paradoxes of food safety regulation, Environ. Planning A 35, 1493-1511.

Elkington J. (1998) Cannibals with Forks: the Triple Bottom Line of 21st Century Business.

Fiksel J. (2006) Sustainability and resilience: towards a systems approach, Sustain. Sci. Practice Policy 2, 14-21.

Gibbons M., Limoges C., Nowotny H., Schwartzman S., Scott P., Trow M. (1994) The new production of knowledge: The Dynamics of Science and Research in contemporary societies London, Sage.
Giller K.E., Leeuwis C., Anderson J.A., Andriesse W., Brouwer A., Frost P., Hebinck P., Heitkönig I., Ittersum M.K., Koning N., Ruben R., Slingerland M., Udo H., Veldkamp A., van de Vijver C., van Wijk, M.T., Windmeijer P. (2008) Competing claims of natural resources: What is the role of Science, Ecol. Soc. (in press).

Lawrence R.J., Després C. (2004) Futures of Transdisciplinarity, Futures 36, 397-405.

Liu J., Dietz T., Carpenter S.R., Alberti M., Folke C., Moran E., Pell A.N., Deadman P., Kratz T., Lubchenco J., Ostrom E., Ouyang Z., Provencher W., Redman C.L., Schneider S.H., Taylor W.W. (2007) Complexity of Coupled Human and Natural Systems, Science 14, 1513-1516.

Lebel L., Anderies J.M., Campbell B., Folke C., Hatfield-Dodds S., Hughes T.P., Wilson J. (2006) Governance and the capacity to manage resilience in regional social-ecological systems, Ecol. Soc. 11, 19.

Leeuwis C. (2000) Reconceptualizing participation for sustainable rural development: Towards a negotiation approach, Dev. Change 31, 931-959.

Maris A., de Veer J. (1973) Dutch agriculture in the period 1950-1970 and a look ahead, Eur. Rev. Agr. Econ. 1, 63-78.

Martens P. (2006) Sustainability: science or fiction? Sustain. Sci. Practice Policy 2. Available online: http://ejournal.nbii.org/archives/vol2iss1/communityessay.martens.pdf

Newman L. (2005) Uncertainty, innovation, and dynamic sustainable development, Sustain. Sci. Practice Policy 1. Available online: http://ejournal.nbii.org/archives/vol1iss2/0501-001.newman.pdf

Nowotny H., Scott P., Gibbons M. (2003) Introduction: 'Mode 2' Revisited: The New Production of Knowledge, Minerva 3, 179194.

Pedroli B., van Doorn A., de Blust G., Parachini M.L., Wascher D., Bunce F. (Eds.) (2007) Europe's living landscapes. Essays exploring our identity in the countryside. LANDSCAPE EUROPE, Wageningen KNNV publishing Zeist Netherlands, $432 \mathrm{p}$.

Pohl C., Hirsch Hadorn G. (2007) Principles for Designing Transdisciplinary Research - proposed by the Swiss Academies of Arts and Sciences, oekom Verlag, München, 120 p.

Polanyi M. (1966) The Tacit Dimension, Garden City, Doubleday \& Co. N.Y.

Porter M.E. (1990) The Competitive Advantage of Nations, Harvard Business Review 90211, 857 p.

Porter M.E. (2000) Location, competition, and economic development: local clusters is global economy, Economic Development Quarterly $14,15-34$

Porter M.E. (2003) The economic performance of regions, Regional Studies 37, 549-578.

Rotmans J. (2003) Transitiemanagement: sleutel naar een duurzame samenleving, van Gorcum Uitgeverij, Assen.

Stoker G., Mossberger K. (1994) Urban Regime Theory in Comparative Perspective, in: Environment and Planning, C, Government and Policy, 12, 195-212.

Thomson G.R. (2002) Foot and mouth disease: facing the new dilemmas, Sci. Techn. Rev. 21, 498

Verburg P.H., Rounsevell M.D.A., Veldkamp A. (2006a) Scenario based studies of future land use in Europe, (Editorial), Agr. Ecosyst. Environ. 114, 1-6.

Verburg P.H., Schulp C.J.E., Witte N., Veldkamp A. (2006b) Downscaling of land use scenarios to assess the dynamics of European landscapes, Agr. Ecosyst. Environ. 114, 39-56.

Wiskerke J.S.C., Van der Ploeg J.D. (Eds.) (2004) Seeds of transition: essays on novelty production, niches and regimes in agriculture, Van Gorcum, Assen. 